\title{
Interactions among members of the microbial loop in an estuary dominated by microzooplankton grazing
}

\author{
Natalie Ortell ${ }^{1,2}$, Alice C. Ortmann ${ }^{1,2, *}$ \\ ${ }^{1}$ University of South Alabama, 307 N University Boulevard, Mobile, Alabama 36688-0002, USA \\ ${ }^{2}$ Dauphin Island Sea Laboratory, 101 Bienville Boulevard, Dauphin Island, Alabama 36528, USA
}

\begin{abstract}
Modified dilution experiments were employed to characterize the microbial loop in surface waters at sites along an estuarine-offshore gradient in the northern Gulf of Mexico. Estuarine surface waters were more variable than those offshore due to the strong influence of river discharge. Phytoplankton (chlorophyll a) and prokaryotes were both significantly higher in the estuary than offshore, but virus and heterotrophic nanoflagellate abundances did not differ across the gradient. Grazing was detected in the majority of experiments, while viral lysis was only detected in $24 \%$ of phytoplankton and $12 \%$ of prokaryote experiments. Growth and grazing rates for both phytoplankton and prokaryotes were tightly coupled, except for locations within strong environmental transition zones. A large, but variable, percentage of phytoplankton ( $83 \pm 149 \%$ ) and prokaryote $(70 \pm 64 \%)$ production was grazed by microzooplankton across the estuary. While microzooplankton grazing is responsible for the removal of the majority of microbial production, thus supporting productivity of higher trophic levels, the role of viral lysis remains unclear.
\end{abstract}

KEY WORDS: Grazing $\cdot$ Viral lysis $\cdot$ Estuaries $\cdot$ Nutrient limitation $\cdot$ Microbial loop

\section{INTRODUCTION}

Phytoplankton and prokaryote communities in estuaries are complex, responding to variable physical parameters and nutrient concentrations. The complexity of estuarine ecosystems is driven by the variability in freshwater inputs mixing with marine sources, producing gradients in salinity, turbidity and nutrient concentrations (Cloern \& Jassby 2010). Estuaries, such as Mobile Bay, Alabama are important systems that provide valuable nursery and recruitment habitat for economically significant species, such as shrimp and finfish (Beck et al. 2001). Both top-down and bottom-up effects play important roles in estuary production. Top-down controls, such as mesozooplankton grazing, may reduce microzooplankton grazer populations, allowing phytoplankton species to bloom, altering the overall microbial community structure (Buskey et al. 1997, Murrell et al. 2002a). Alternatively, large riverine input can relieve nutrient limitations and stimulate phytoplankton growth rates (Conley \& Malone 1992). Competition between phytoplankton and heterotrophic prokaryotes for inorganic nutrients may also shape estuary production (Davidson et al. 2007).

Microzooplankton includes heterotrophic ciliates and nanoflagellates, which consume prokaryotes and phytoplankton. Microzooplankton are efficient grazers of primary production, capable of removing up to $100 \%$ of phytoplankton biomass each day (McManus \& Ederington-Cantrell 1992, Dagg 1995). Understanding the relationship between grazing and production is important because of the cumulative impacts on nutrient regeneration and, ultimately, productivity of higher trophic levels. Specifically, microzooplankton waste products have high nitrogen $(\mathrm{N})$ concentrations, which can be increasingly important when nutrient availability is low. Within 
Mobile Bay, 39\% of the phytoplankton $\mathrm{N}$ demand could be met through regeneration by microzooplankton, while only $20 \%$ of the demand could be met in offshore areas (Lehrter et al. 1999). Viral lysis can also remove prokaryote and phytoplankton production; however, the viral shunt returns most of the biomass to the dissolved organic matter pool, which becomes unavailable to higher trophic levels (Fuhrman 1999, Wilhelm \& Suttle 1999). This shunt may contribute to nutrient regeneration and the alleviation of $\mathrm{P}$ or $\mathrm{N}$ limitation that can occur in the shallow estuaries of the northern Gulf of Mexico (nGOM) (Murrell et al. 2002b, Juhl \& Murrell 2008). Thus, the balance between microzooplankton grazing and viral lysis can affect the flow of energy through the microbial food web.

Previous studies in the nGOM have suggested that temperature controls the production of prokaryotes (McManus et al. 2004), but that grazing and viral lysis may exert some control on these organisms throughout the year (Ortmann et al. 2011). The majority of primary production was grazed within the bay, with a smaller percentage consumed offshore, suggesting that microzooplankton grazing is important in controlling coastal phytoplankton production (Lehrter et al. 1999). Using high-performance liquid chromatography (HPLC) to look at grazing and lysis of specific phytoplankton groups, it was clear that not all phytoplankton are grazed or lysed equally, and that the rates vary over time and space (Ortmann et al. 2011). Lysis of phytoplankton was detected during fall and winter, but not during the summer. However, this observation was based on only 3 sampling times and does not indicate how the rates of grazing and lysis change throughout the year.

In the present study, modified dilution experiments were applied to examine the impact of both microzooplankton grazing and viral lysis on phytoplankton and heterotrophic prokaryote production along an estuarine-offshore gradient from Mobile Bay to the nGOM shelf. Samples collected over 2 yr were analyzed to determine whether (1) microzooplankton grazing was more prevalent than viral lysis in removing phytoplankton and prokaryotes and (2) the rates of growth and microzooplankton grazing changed significantly across the gradient.

\section{MATERIALS AND METHODS}

From January 2010 to December 2011, 4 stations were sampled along an estuarine-offshore gradient beginning within the Mobile Bay estuary and contin- uing $78 \mathrm{~km}$ out onto the shelf in the nGOM (Fig. 1). A surface sample from each station was collected approximately every other month (46 samples in total). A Seabird 19+ CTD measured temperature, salinity and dissolved oxygen. To remove large grazers, such as copepods, samples were pre-filtered through a $150 \mu \mathrm{m}$ Nitex mesh and collected in $22 \mathrm{l}$ opaque carboys that were transported to the Dauphin Island Sea Laboratory for processing. Subsamples were analyzed for nutrients (dissolved inorganic nitrogen [DIN]: $\mathrm{NO}_{2}{ }^{-}, \mathrm{NO}_{3}{ }^{-}, \mathrm{NH}_{4}{ }^{+}$; dissolved organic nitrogen $[\mathrm{DON}=$ total $\mathrm{N}-\mathrm{DIN}] ; \mathrm{PO}_{4}{ }^{-3}$; dissolved silicate [DSi]) using a Skalar SAN+ autoanalyzer (Whitledge et al. 1981). The discharge of freshwater into Mobile Bay was calculated using the flow rates of the Tombigbee River at the Coffeeville Dam (US Geological Survey gauging station \#02469765) and the Alabama River at the Clairborne Dam (USGS $\#$ 02429500). Flow rates for the $7 \mathrm{~d}$ prior to sampling were averaged and total discharge estimated using the formula $1.07 \times$ Alabama River flow + Tombigbee River flow (Schroeder 1978, Stumpf et al. 1993).

The modified dilution experiment (Landry \& Hassett 1982, Evans et al. 2003, Ortmann et al. 2011) was utilized to estimate growth, grazing and viral lysis rates for phytoplankton and heterotrophic prokaryotes for each sample. Experiments took place over $\sim 24 \mathrm{~h}$ following the day-night cycle. Two simultaneous dilution series were monitored, one in which whole water (WW, $150 \mu \mathrm{m}$ screened) was diluted with $0.22 \mu \mathrm{m}$ filtered water to determine grazing rates,

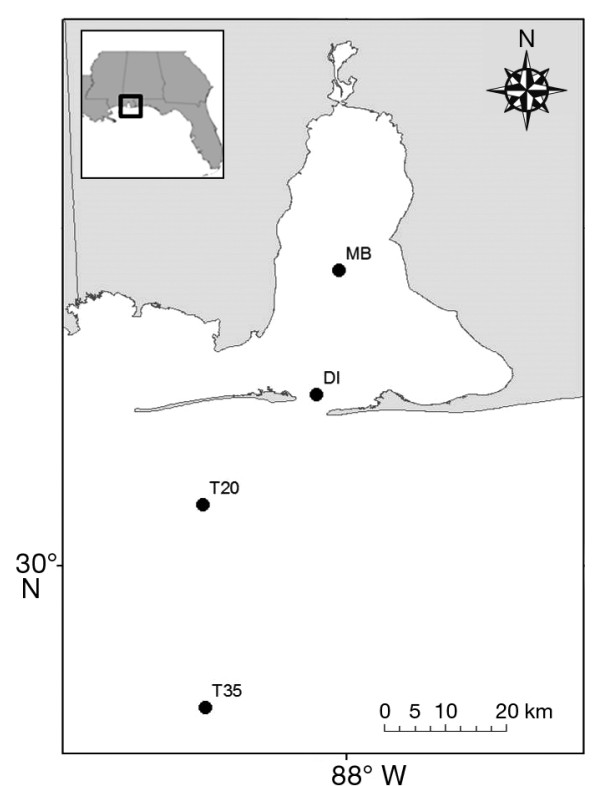

Fig. 1. Sampling sites (MB, DI, T20 and T35), from Mobile Bay, Alabama to the nGOM shelf. Map created in ArcGIS 
and another in which WW was diluted with $30 \mathrm{kDa}$ filtered water to measure rates of grazing plus viral lysis. A peristaltic pump (Masterflex, LS easy-load II) at low speed was used to filter the WW through a $0.7 \mu \mathrm{m}$ glass-fiber filter followed by a $0.22 \mu \mathrm{m}$ Durapore filter (Millipore). Half of the $0.22 \mu \mathrm{m}$ filtered water was used for the grazing experiment, while the other half was filtered through a $30 \mathrm{kDa}$ cartridge using tangential flow filtration to remove viruses. The filtrate from this process was used for the viral lysis experiments. For each dilution series, 3 dilutions were used: 30, 50, 70\% WW each in triplicate, with 3 additional bottles containing $100 \%$ WW (21 in total). Nutrients $\left(2 \mu \mathrm{M} \mathrm{NH}_{4} \mathrm{NO}_{3}\right.$ and $\left.0.1 \mu \mathrm{M} \mathrm{Na}_{2} \mathrm{HPO}_{4}\right)$ were added to all samples to prevent nutrient limitation. Additionally, 3 bottles containing 100\% WW without added nutrients were used to determine whether groups were nutrient limited for each experiment.

Filtration was carried out under low light, and incubations began near or after dusk. Experiments were carried out in acid-washed $(10 \% \mathrm{HCl}) 11$ clear polycarbonate bottles in a submersible cage attached to the boat dock at the Dauphin Island Sea Laboratory. The cage was built from PVC pipes and green mesh. The cage was submerged to a shallow depth maintaining light levels similar to where samples were collected, and large enough to prevent shading from the other bottles. To determine rates for prokaryotes, samples were collected at time $t=0$ and $12 \mathrm{~h}$ and at the end of the experiments, between $t=20$ and $24 \mathrm{~h}$. For phytoplankton, samples were collected at $t=0$ and at the end of the experiments. At $t=0$, samples were also collected to determine the abundance of heterotrophic nanoflagellates (HNFs) and viruses in the WW.

Prokaryotes and viruses were quantified using flow cytometry, while HNFs were quantified using epifluorescence microscopy. At each time point, $5 \mathrm{ml} \mathrm{sam-}$ ples were collected and fixed with $0.5 \%$ EM grade glutaraldehyde. After $15 \mathrm{~min}$, samples were flash frozen in liquid $\mathrm{N}_{2}$ and stored at $-80^{\circ} \mathrm{C}$ until further analysis (Wen et al. 2004). For HNFs, $3 \mathrm{ml}$ of sample from $t=0$ was filtered onto $0.8 \mu \mathrm{m}$ black polycarbonate filters (25 mm) and stained with 4', 6-diamidino-2phenylindole (DAPI, $1.0 \mathrm{mg} \mathrm{ml}^{-1}$ ). The filter was washed twice with filtered distilled water and dried before being mounted on a glass slide with an antifade mixture (Sherr et al. 1993). HNFs were counted on an Olympus BH-2 microscope using UV light. Viruses and prokaryotes were counted using a FACSCalibur (BD Biosciences) flow cytometer. For virus enumerations, samples from $t=0$ were diluted 100 times with filtered Tris-EDTA (TE, 1.0 M Tris- $\mathrm{HCl}$, 0.5 M EDTA,
$\mathrm{pH}$ 8.0), stained with SYBR Green I (Lonza) for $15 \mathrm{~min}$ at $80^{\circ} \mathrm{C}$ and run on a medium flow rate for 2 min (Brussaard et al. 2000, Payet \& Suttle 2008). Sample flow rate was determined following the protocol of Brussaard et al. (2010). Virus abundance was calculated from the number of viruses detected, the flow rate and the length of data collection. Prokaryote abundances were determined for samples collected at $t=0$ and 12 and $t=$ end, but were diluted 10 times in TE and were incubated for $10 \mathrm{~min}$ at room temperature with SYBR Green I (Payet \& Suttle 2008). Samples were run for 2 to $3 \mathrm{~min}$ at a medium flow rate, with the exact time recorded to enable abundances to be calculated.

Phytoplankton abundance was estimated based on the concentration of chlorophyll a ( $\mathrm{chl} a$ ). At $t=0$ and $t=$ end, samples from each dilution were gently filtered onto $25 \mathrm{~mm}$ glass fiber filters $(0.7 \mu \mathrm{m})$ until color was observed, and the volume recorded. For experiments carried out in January 2010, pigments were extracted and measured using HPLC (Ortmann et al. 2011). For the remainder of the experiments, chl a was extracted using a mixture of $90 \%$ acetone and dimethyl sulfoxide (Shoaf \& Lium 1976) and quantified using a Turner TD-700 fluorometer calibrated with a purified standard (Sigma-Aldrich).

For each experiment, the prokaryote and phytoplankton data were analyzed separately. For each bottle, the apparent prokaryote and phytoplankton growth rates were calculated using the change in the abundance of cells and the change in the concentration of chl $a$, respectively, over the course of the experiment. The apparent growth rates were then regressed against the dilution to generate estimates of grazing rates $(0.22 \mu \mathrm{m}$ dilutions $)$ or grazing + viral lysis rates (30 kDa dilutions) from the slopes of the regressions (Landry \& Hassett 1982). When regressions were significant for both analyses, an F-test was used to determine whether the slopes were significantly different (Kimmance et al. 2007). When no significant difference was observed, viral lysis was determined to be below detection limits. When the $F$ test indicated a significant difference in slopes, viral lysis was calculated by subtracting the grazing rate from the grazing + viral lysis rate (Evans et al. 2003).

Growth rates were calculated differently depending on the results of the regression analyses. When regressions were not significant, the growth rates were determined to be the average growth rate in the $100 \%$ WW treatments without added nutrients. When either grazing or grazing + viral lysis regressions were significant and the slope of the regression negative, the growth rate was determined from the 
$y$-intercept. This value was adjusted if the growth rate in the $100 \% \mathrm{WW}$ with nutrients was significantly higher ( $t$-test) than in the no nutrient addition controls (Landry \& Hassett 1982, Andersen et al. 1991). For some experiments, significant regressions resulted in positive slopes. For these experiments, growth rates were determined from the $100 \% \mathrm{WW}$ treatments without nutrient addition (Ortmann et al. 2011). The percentage of growth grazed was calculated from the ratio of the grazing rate to the growth rate. Negative grazing rates were considered to be zero for these calculations.

Data were not normally distributed and transformations could not correct for this; therefore, nonparametric analyses were used. Correlations were calculated using Spearman's rho $(\rho)$ to identify relationships between growth and grazing rates. The nonparametric Wilcoxon signed-rank test (JMP 9, SAS Institute) was used to examine differences in environmental variables, abundance, grazing and growth rates between sites. The Wilcoxon signedrank test was also employed to determine the impact of nutrient limitation on abundances and growth rates for both prokaryotes and phytoplankton. All tests were deemed significant at $\alpha=0.05$. Environmental variables were $\log (x+2)$ transformed, normalized and pairwise Euclidean distances calculated. Similarities in sample characteristics across locations were visualized using multidimensional scaling in Primer 6 (Primer E).

\section{RESULTS}

\section{Environmental variables}

From January 2010 to December 2011, 46 samples were collected along an estuarine-offshore gradient (Table S1 in the Supplement at www.int-res.com/ articles/suppl/a072p063_supp.xls). The environment at the estuarine sites (MB and DI) exhibited greater variability than at the offshore sites (T20 and T35) (Fig. 2), primarily due to freshwater input. River discharge varied annually, ranging from 283 to $6865 \mathrm{~m}^{3}$ $\mathrm{s}^{-1}$, with higher freshwater input during cooler times

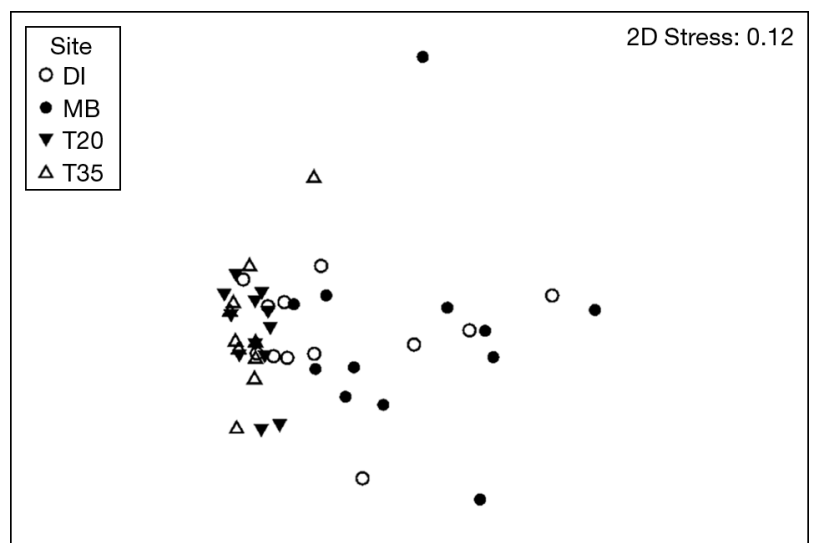

Fig. 2. Multidimensional scaling plot showing the environmental variability at each site, based on the Euclidean distance between samples calculated using environmental variables

Table 1. Ranges of environmental and biological parameters for the 4 sampling sites: MB ( $n=12), D I(n=12), T 20(n=12)$ and T35 ( $\mathrm{n}=10)$. For specific sample values, see Table S1 in the Supplement. Different letters indicate where significant differences were observed between sites (Wilcoxon, $\mathrm{p}<0.05$ )

\begin{tabular}{|c|c|c|c|c|}
\hline & $\mathrm{MB}$ & DI & T20 & T35 \\
\hline Temperature $\left({ }^{\circ} \mathrm{C}\right)$ & $6.5-31.7$ & $6.4-30.4$ & $11.7-30.5$ & $12.4-31.0$ \\
\hline Salinity & $0.7-21.8^{\mathrm{A}}$ & $3.8-30.0^{\mathrm{B}}$ & $23.5-33.6^{\mathrm{C}}$ & $26.1-35.5^{\mathrm{C}}$ \\
\hline Dissolved inorganic nitrogen $(\mu \mathrm{M})$ & $0.5-15.1$ & $0.08-13.3$ & $0.26-3.9$ & $0.28-7.8$ \\
\hline $\mathrm{PO}_{4}^{-3}(\mu \mathrm{M})$ & $0.08-1.45$ & $0.09-0.6$ & $0.05-0.4$ & $0.09-0.9$ \\
\hline Dissolved silicate $(\mu \mathrm{M})$ & $7.9-101.1^{\mathrm{A}}$ & $3.8-87.4^{\text {B }}$ & $0.14-14.2^{\mathrm{C}}$ & $1.1-17.6^{\mathrm{C}}$ \\
\hline Dissolved organic nitrogen $(\mu M)$ & $14.0-74.5$ & $10.7-63.1$ & $9.6-51.0$ & $10.9-54.0$ \\
\hline Phytoplankton $\left(\mu \mathrm{g}^{-1}\right)$ & $2.7-22.3^{\mathrm{A}}$ & $1.0-24.8^{\mathrm{A}}$ & $0.3-6.4^{\mathrm{B}}$ & $0.3-2.0^{\mathrm{C}}$ \\
\hline Virus $\left(1^{-1}\right)$ & $9.4 \times 10^{6}-1.5 \times 10^{8}$ & $7.9 \times 10^{6}-1.6 \times 10^{8}$ & $2.0 \times 10^{6}-1.5 \times 10^{8}$ & $8.1 \times 10^{6}-8.4 \times 10^{7}$ \\
\hline Heterotrophic nanoflagellates $\left(\mathrm{l}^{-1}\right)$ & $5.6 \times 10^{3}-2.3 \times 10^{5}$ & $1.4 \times 10^{4}-1.9 \times 10^{5}$ & $6.8 \times 10^{3}-2.2 \times 10^{5}$ & $3.1 \times 10^{4}-1.5 \times 10^{5}$ \\
\hline Prokaryotes $\left(\mathrm{ml}^{-1}\right)$ & $3.2 \times 10^{5}-1.2 \times 10^{7 \mathrm{~A}}$ & $2.7 \times 10^{5}-7.3 \times 10^{6 \mathrm{~A}}$ & $8.6 \times 10^{5}-4.7 \times 10^{6}$ B & $6.2 \times 10^{5}-5.6 \times 10^{6}$ А в \\
\hline Phytoplankton grazing $\left(\mathrm{g} \mathrm{d}^{-1}\right)$ & $0-2.4$ & $0-2.0$ & $-0.2-1.9$ & $0-1.6$ \\
\hline Phytoplankton lysis $\left(\mathrm{l} \mathrm{d}^{-1}\right)$ & $-1.3-1.2$ & $-2.3-0.3$ & $-0.9-0$ & $-1.3-0.4$ \\
\hline Phytoplankton growth $\left(\mathrm{d}^{-1}\right)$ & $-0.6-2.4$ & $-0.2-2.4$ & $-0.6-1.4$ & $-0.03-2.4$ \\
\hline Prokaryote grazing $\left(\mathrm{g} \mathrm{d}^{-1}\right)$ & $0-1.5$ & $-1.6-3.7$ & $-0.7-2.0$ & $0-1.6$ \\
\hline Prokaryote lysis $\left(\mathrm{l} \mathrm{d}^{-1}\right)$ & $0-0$ & $0-0.8$ & $-0.7-1.4$ & $0-1.1$ \\
\hline Prokaryote growth $\left(\mathrm{d}^{-1}\right)$ & $0.3-1.4$ & $-0.14-3.3$ & $-0.13-0.8$ & $-0.15-1.9$ \\
\hline Phytoplankton growth grazed (\%) & $0-298$ & $0-856$ & $0-371$ & $0-179$ \\
\hline Prokaryote growth grazed (\%) & $0-173$ & $0-302$ & $0-70$ & $0-109$ \\
\hline
\end{tabular}


of the year. Samples collected from MB and DI sometimes displayed similar characteristics to T20 and T35, but were very different at other times. The offshore sites, T20 and T35, exhibited a more stable environment with little variability.

Significant differences in DSi and salinity were detected between the 2 ends of the gradient (MB and T35), although the range for most variables was highest at MB and smallest at T35. At MB, salinity and temperature ranged from 0.7 to $21.8 \mathrm{psu}$ and 6.5 to $31.7^{\circ} \mathrm{C}$, respectively (Table 1 ). In comparison, salinity and temperature at T35 ranged from 26.1 to $35.5 \mathrm{psu}$ and 12.4 to $31.0^{\circ} \mathrm{C}$, respectively. T35 and T20 had significantly higher salinity compared with DI and $\mathrm{MB}$, but did not differ from each other (Wilcoxon, $\mathrm{p}<$ 0.0001). DSi concentrations were greatest at the estuarine sites, and MB was significantly higher than DI, T20 and T35 (Wilcoxon, p < 0.0001) (Table 1).

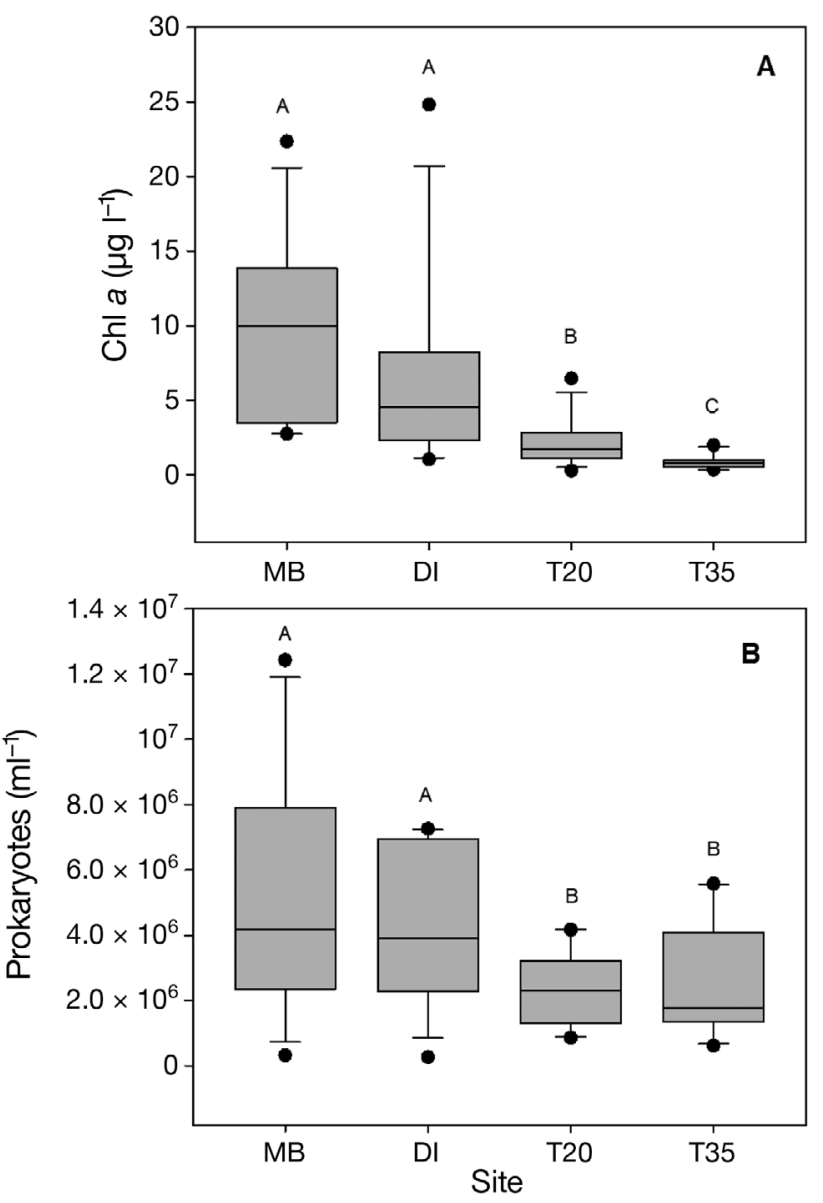

Fig. 3. Abundance of (A) phytoplankton and (B) prokaryotes at 2 estuarine sites (MB, DI) and 2 offshore sites (T20, T35; see Fig. 1 for locations). Boxplots represent median, 25 to $75 \%$ interquartile range and non-outlier range; points beyond are outliers. Different letters above boxes indicate significant difference between sites (Wilcoxon, $\mathrm{p}<0.05$ )

\section{Abundance}

Phytoplankton abundance, based on chl a concentrations, decreased with distance from shore (Fig. 3A). MB had significantly higher phytoplankton abundance than T20 and T35, but was not significantly higher than DI (Wilcoxon, $\mathrm{p}<0.0001$ ). Phytoplankton abundance at T20 was lower than both MB and DI, but higher than T35. Similarly, prokaryote abundance decreased across the gradient (Wilcoxon, $\mathrm{p}=$ 0.0254) (Fig. 3B). As with phytoplankton, MB had significantly higher prokaryote abundance than T20 and T35. Distance from the estuary did not have a significant impact on viral abundance (Wilcoxon, $\mathrm{p}=$ 0.4153) (Fig. 4A). As with the viruses, there was no significant difference in the abundance of HNFs across the gradient (Wilcoxon, $\mathrm{p}=0.06335$ ), but HNFs did show high variability (Fig. 4B).
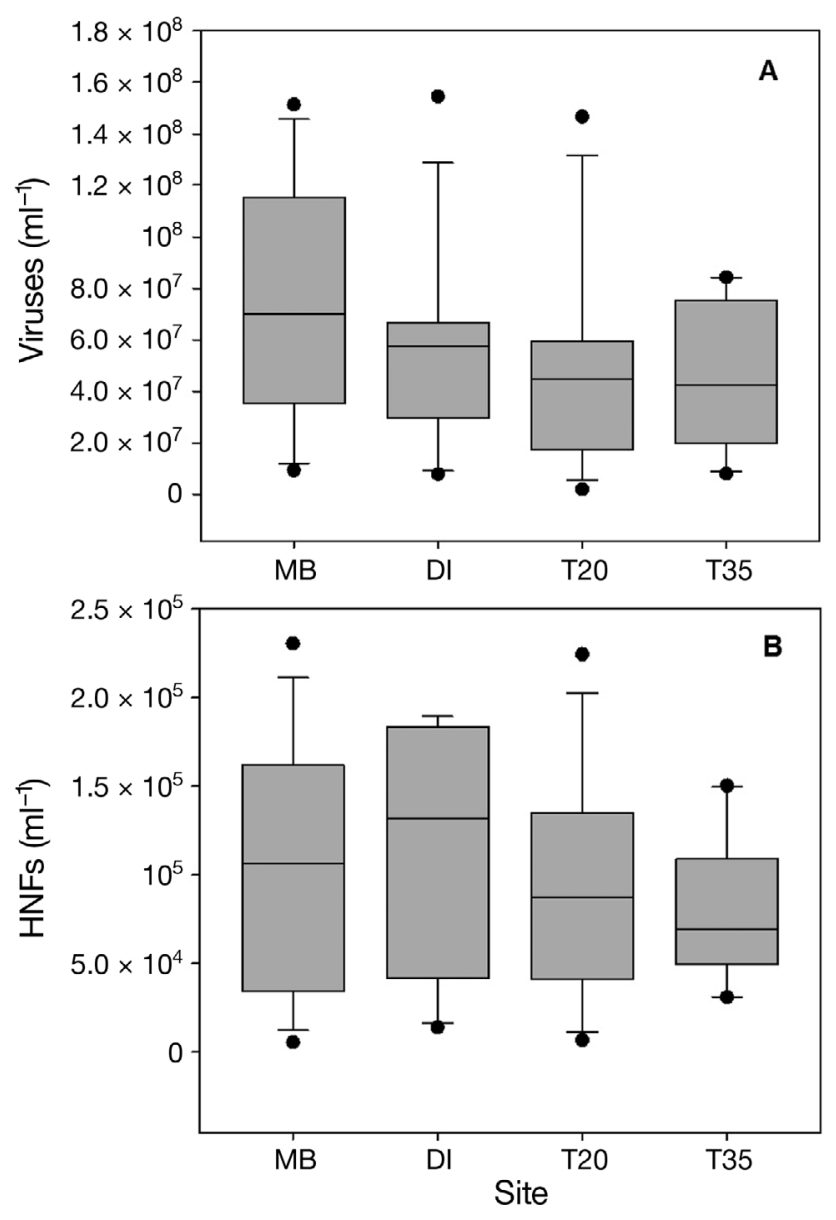

Fig. 4. Abundance of (A) viruses and (B) heterotrophic nanoflagellates (HNFs) at 2 estuarine sites (MB, DI) and 2 offshore sites (T20, T35; see Fig. 1 for locations). Boxplots represent median, 25 to $75 \%$ interquartile range and non-outlier range; points beyond are outliers (Wilcoxon, $\mathrm{p}>0.05$ ) 


\section{Growth, grazing and viral lysis rates}

Samples were amended with nutrients $(\mathrm{N}+\mathrm{P})$ to prevent nutrient limitation during experiments. Unamended controls were included to determine whether communities were experiencing nutrient limitation. Prokaryotes and phytoplankton were determined to be limited by DIN and/or $\mathrm{PO}_{4}{ }^{-3}$ in $14(28 \%)$ and 24 $(52 \%)$ of the experiments, respectively, distributed equally across all sites. No clear trends in abundance or growth rates under nutrient limitation were evident. Microbial growth rates under nutrient limitation were not significantly different compared with when nutrients were replete.

Growth and grazing rates of phytoplankton and prokaryotes were tightly coupled along the gradient; however, at some sites this significant relationship did not hold. Phytoplankton growth and grazing rates were positively correlated at MB $(\rho=0.7987)$, DI $(\rho=$ $0.8846)$ and T35 $(\rho=0.8160)$. Prokaryote growth and grazing rates were positively correlated at DI $(\rho=$ $0.8601)$, T20 ( $\rho=0.5744)$ and T35 $(\rho=0.6442)$ (Fig. 5). There were no significant differences in growth or grazing rates across the estuarine-offshore gradient for either phytoplankton (Wilcoxon, $\mathrm{p}=0.0947, \mathrm{p}=$ 0.2812 ) or prokaryotes (Wilcoxon, $\mathrm{p}=0.4796, \mathrm{p}=$ 0.6713). For both microbial groups, the relationship between grazing and growth was less than 1:1 when all samples were pooled (Fig. 5A,B). Within the estuary, the relationship was greater than 1:1, suggesting that microbial growth was unable to overcome grazing pressure. Most of the microbial production was consumed by grazers, although the percentage varied across samples. On average, microzooplankton consumed $70 \pm 64 \%$ of prokaryote production and $83 \pm 149 \%$ of phytoplankton production.

Measurable viral lysis was detected throughout the study, but only in 4 prokaryote and 12 phytoplankton experiments. While lysis of phytoplankton was detected at all sites, lysis of prokaryotes was never detected at MB. The small number of experiments with non-zero estimates of lysis prevented any clear patterns of lysis from being detected.

\section{DISCUSSION}

The modified dilution method has been used in multiple ecosystems to simultaneously assess the impact of microzooplankton grazing and viral lysis on phytoplankton and prokaryote growth rates (Evans et al. 2003, Tijdens et al. 2008, Chen et al. 2009, Gutiérrez-Rodríguez et al. 2011, Ortmann et al. 2011).
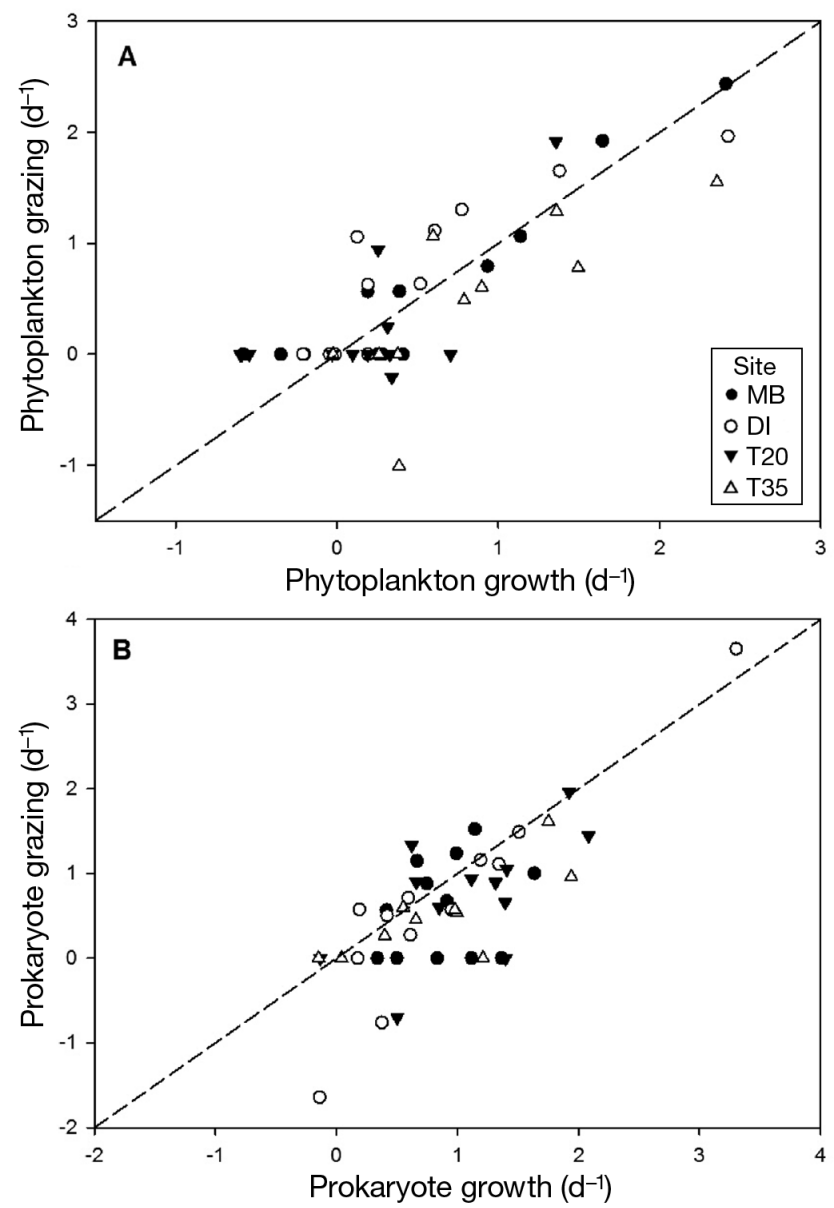

Fig. 5. Relationship between growth rates and microzooplankton grazing rates on both (A) phytoplankton and (B) prokaryotes across the estuarine-offshore gradient. The dashed line represents equality of the 2 rates

The method is not without limitations, which may confound the interpretation of the results. For example, the species-specific interactions between viruses and hosts may result in the underestimation of viral lysis rates, because the whole community growth rate may not be altered by viral infection. Furthermore, the method assumes that phytoplankton and prokaryote growth rates are independent of the dilution factor and not limited by nutrients. The addition of inorganic $\mathrm{N}$ and $\mathrm{P}$ in this study ensured that cells were not limited by these nutrients. The multiple filtration steps required by the method may result in the inadvertent release of nutrients and organic matter or cause infected cells to rupture (Shifrin 1980, Fuhrman \& Bell 1985). This could artificially increase the resources available in incubations, altering growth rates of both phytoplankton and prokaryotes. Finally, microzooplankton grazing rates may be impacted by the dilution process itself. Microzooplankton grazing 
intensity may change with changes in prey density (Strom et al. 2001). Even with these limitations, the strength of the method lies in the ability to quantify growth, grazing and viral lysis rates within the same incubations. This enables a more direct comparison between measured rates than if multiple methods were employed.

The dilution method was employed in this study to determine the impact of microzooplankton grazing and viral lysis on microbial communities across an estuarine-offshore gradient. Estuaries typically experience greater environmental variability than offshore waters due to changing nutrient concentrations driven primarily by freshwater discharge (Bong \& Lee 2011, Corcoran \& Shipe 2011). In the nGOM, the estuarine gradient was driven primarily by variable salinity and DSi. Ranges in DIN and $\mathrm{PO}_{4}{ }^{-3}$ concentrations remained fairly constant across the gradient. This lack of a strong gradient in $\mathrm{N}$ and $\mathrm{P}$ was reflected in the presence of nutrient-limited cells at all sites within this study. There was no obvious pattern in when or where cells were nutrient limited. However, the abundance of both phytoplankton and prokaryotes did decrease across the gradient, with higher abundances inshore compared with the offshore waters.

Gradients in nutrient availability and microbial biomass are not always reflected in growth and grazing rates, resulting in variability across similar systems. A study of Long Island Sound and San Francisco Bay, 2 estuaries at different latitudes with differing nutrient concentrations and phytoplankton biomass, did not detect differences in growth or grazing rates of phytoplankton across either estuary or between the 2 systems (York et al. 2010). In contrast, the South China Sea, a eutrophic marginal sea, supports higher bacterial abundance close to the river plume, consistent grazer abundance across the gradient, and higher growth and grazing rates within the river plume (Chen et al. 2009, Bong \& Lee 2011). The nGOM, like the South China Sea, is characterized by greater microbial abundance within the river plume and consistent grazer abundance across sites. However, growth and grazing rates for both phytoplankton and prokaryotes were constant across the estuarine-offshore gradient in the nGOM, similar to the patterns observed in the Long Island Sound and San Francisco Bay study (York et al. 2010). Furthermore, a previous study in the nGOM reported an increase in grazing on phytoplankton from the estuary to offshore sites (Lehrter et al. 1999). The increase in grazing rates across the gradient corresponded to an increase in growth rates of the phytoplankton from within the bay, a pattern not observed in this study. The different patterns in growth and grazing rates across estuaries may be due to variability in factors controlling phytoplankton and prokaryote growth rates. Rivers can increase sediment loads, decreasing light and limiting phytoplankton growth, but can also increase nutrient concentrations, which would have the opposite effect on phytoplankton growth. Grazers likely respond to the growth rates of the phytoplankton and prokaryotes, which is reflected in the strong correlations between rates across most studies.

Microzooplankton grazing rates are often tightly coupled to microbial growth rates in coastal ecosystems; however, changes in environmental factors may result in the uncoupling of this relationship (McManus \& Ederington-Cantrell 1992, Lehrter et al. 1999, Murrell et al. 2002a, Chen et al. 2009, York et al. 2010). The correlation between phytoplankton growth and grazing in this study was similar within the estuary compared with the most offshore site (Fig. 5), as observed in Lehrter et al. (1999). The correlation was not significant at T20. The uncoupling of rates at this location may result from a shift in environmental conditions. The region from DI to T20 has been characterized as a transition zone, where the estuarine and shelf environments mix (Dzwonkowski et al. 2011). For prokaryotes, significant relationships between growth and grazing rates were detected at DI, T20, and T35, but not MB. Uncoupling at MB may be due to the transition from a freshwater to estuarine environment affecting prokaryotic growth rates. Transition zones characterized by variable light availability, salinity and nutrient concentrations may result in a more unpredictable environment for both prey and predator, resulting in an uncoupling of growth and grazing rates.

Microzooplankton grazing has been investigated in many coastal regions around the world, providing support for the substantial impact of microzooplankton grazing on phytoplankton (McManus \& Ederington-Cantrell 1992, Strom et al. 2001, Juhl \& Murrell 2005) and prokaryote (Tsai et al. 2013) production. Using the dilution method, the ratio between grazing and phytoplankton growth in the Puget Sound and Gulf of Alaska averaged 0.640 (Strom et al. 2001), while the grazing and prokaryote growth ratio in the Changjiang River averaged 0.704 (Tsai et al. 2013). Similarly, in the present study, the average ratio of grazing to growth for phytoplankton and prokaryotes was 0.797 and 0.830 , respectively. In other words, grazing rates often exceeded $50 \%$ of microbial growth in Mobile Bay and other estuaries, suggesting that microzooplankton grazing is efficient at transferring primary production to higher trophic 
levels (Azam et al. 1983, Coffin \& Connolly 1997). Overall, microzooplankton grazing can remove a sizeable proportion of microbial production.

Viral lysis may also be important for phytoplankton and prokaryote growth because of its role in nutrient remineralization. A previous study in Mobile Bay detected viral lysis under low nutrient, low biomass and cold temperature conditions suggesting that nutrient regeneration by viral lysis may be important under certain environmental conditions (Ortmann et al. 2011). Weinbauer et al. (2011) examined the effects of viral lysis on Synechococcus, and determined that growth decreased when viruses were reduced, implying that phytoplankton growth is dependent on the regeneration of nutrients through viral lysis. Other studies have shown that increasing the abundance of viruses actually reduces phytoplankton growth rates (Suttle et al. 1990, Suttle \& Chen 1992), but ultimately leads to higher phytoplankton yields. In a eutrophic lake, microzooplankton grazing had the greatest impact on bacterial and phytoplankton mortality in summer, while viral lysis was the main control of mortality in winter (Tijdens et al. 2008). Microzooplankton grazing and viral lysis removed 33.3 to $66.7 \%$ and 13.1 to $137.8 \%$, respectively, of daily bacterial production in the East China Sea (Tsai et al. 2012). While grazing on prokaryotes in Mobile Bay removed larger proportions of daily production than measured in the East China Sea (0 to $302 \%$ ), viral lysis removed variable proportions (0 to $433 \%$ ) and was detected infrequently. Viral lysis did not appear to directly or predictably impact microbial abundances in the Mobile Bay estuary; however, viral abundance is variable across seasons, suggesting that viral lysis may control another aspect of the microbial community, such as diversity.

Few studies have investigated both microzooplankton grazing and viral lysis in marine systems (Weinbauer \& Peduzzi 1995, Evans et al. 2003, Kimmance et al. 2007, Tijdens et al. 2008, Fonda Umani et al. 2010, Ortmann et al. 2011, Tsai et al. 2012, Tsai et al. 2013). In these studies, microzooplankton grazing is consistently determined to be the major removal mechanism of microbial production, while the importance of viral lysis appears to vary across seasons and ecosystems. Over the 2 yr sampled in this study, we have shown that microzooplankton grazing represents an important sink for prokaryote and phytoplankton production across the estuary to the shelf. However, the detection of significant viral lysis in so few experiments suggests that infection may be a potential source of microbial mortality, but more often may be involved in structuring community composition across the gradient.
Acknowledgements. The authors gratefully acknowledge the help and support of the FOCAL laboratory, L. Linn, R. Condon and the members of the Marine Microbial Ecology Lab at the Dauphin Island Sea Laboratory. This work was supported by the BP Northern Gulf Institute Year 1 and 2 grants to A.C.O.

\section{LITERATURE CITED}

Andersen T, Schartau AKL, Paasche E (1991) Quantifying external and internal nitrogen and phosphorus pools, as well as nitrogen and phosphorus supplied through remineralization, in coastal marine plankton by means of a dilution technique. Mar Ecol Prog Ser 69:67-80

Azam F, Fenchel T, Field JG, Gray JS, Meyer-Reil LA, Thingstad F (1983) The ecological role of water-column microbes in the sea. Mar Ecol Prog Ser 10:257-263

Beck MW, Heck KL Jr, Able KW, Childers DL and others (2001) The identification, conservation, and management of estuarine and marine nurseries for fish and invertebrates: a better understanding of the habitats that serve as nurseries for marine species and the factors that create site-specific variability in nursery quality will improve conservation and management of these areas. BioScience 51:633-641

Bong CW, Lee WL (2011) The contribution of heterotrophic nanoflagellate grazing towards bacterial mortality in tropical waters: comparing estuaries and coastal ecosystems. Mar Freshw Res 62:414-420

Brussaard CPD, Marie D, Bratbak G (2000) Flow cytometric detection of viruses. J Virol Methods 85:175-182

Brussaard CPD, Payet JP, Winter C, Weinbauer MG (2010) Quantification of aquatic viruses by flow cytometry. In: Wilhelm SW, Weinbauer MG, Suttle CA (eds) Manual of aquatic viral ecology. American Society of Limnology and Oceanography, Waco, TX, p 102-109

Buskey EJ, Montagna PA, Amos AF, Whitledge TE (1997) Disruption of grazer populations as a contributing factor to the initiation of the Texas brown tide algal bloom. Limnol Oceanogr 42:1215-1222

Chen B, Liu H, Landry MR, Dai M, Huang B, Sun J (2009) Close coupling between phytoplankton growth and microzooplankton grazing in the western South China Sea. Limnol Oceanogr 54:1084-1097

Cloern JE, Jassby AD (2010) Patterns and scales of phytoplankton variability in estuarine-coastal ecosystems. Estuaries Coasts 33:230-241

Coffin RB, Connolly JP (1997) Bacteria and heterotrophic microflagellate production in the Santa Rosa Sound, Florida. Hydrobiologia 353:53-61

> Conley DJ, Malone TC (1992) Annual cycle of dissolved silicate in Chesapeake Bay: implications for the production and fate of phytoplankton biomass. Mar Ecol Prog Ser 81: 121-128

Corcoran AA, Shipe RF (2011) Inshore-offshore and vertical patterns of phytoplankton biomass community composition in Santa Monica Bay, CA (USA). Estuar Coast Shelf Sci 94:24-35

> Dagg MJ (1995) Ingestion of phytoplankton by the microand mesozooplankton communities in a productive subtropical estuary. J Plankton Res 17:845-857

Davidson K, Gilpin LC, Hart MC, Fouilland E and others (2007) The influence of the balance of inorganic and organic nitrogen on the trophic dynamics of microbial 
food webs. Limnol Oceanogr 52:2147-2163

Dzwonkowski B, Park K, Ha HK, Graham WM, Hernandez FJ, Powers SP (2011) Hydrographic variability on a coastal shelf directly influenced by estuarine outflow. Cont Shelf Res 31:939-950

Evans C, Archer SD, Jacquet S, Wilson WH (2003) Direct estimates of the contribution of viral lysis and microzooplankton grazing to the decline of a Micromonas spp. population. Aquat Microb Ecol 30:207-219

Fonda Umani S, Malisana E, Focaracci F, Magagnini M, Corinaldesi C, Danovaro R (2010) Disentangling the effect of viruses and nanoflagellates on prokaryotes in bathypelagic waters of the Mediterranean Sea. Mar Ecol Prog Ser 418:73-85

Fuhrman JA (1999) Marine viruses and their biogeochemical and ecological effects. Nature 399:541-548

Fuhrman JA, Bell TM (1985) Biological considerations in the measurement of dissolved free amino acids in seawater and implications for chemical and microbiological studies. Mar Ecol Prog Ser 25:13-21

Gutiérrez-Rodríguez A, Latasa M, Scharek R, Massana R, Vila G, Gasol JM (2011) Growth and grazing rate dynamics of major phytoplankton groups in an oligotrophic coastal site. Estuar Coast Shelf Sci 95:77-87

Juhl AR, Murrell MC (2005) Interactions between nutrients, phytoplankton growth, and microzooplankton grazing in a Gulf of Mexico estuary. Aquat Microb Ecol 38:147-156

Juhl AR, Murrell MC (2008) Nutrient limitation of phytoplankton growth and physiology in a subtropical estuary (Pensacola Bay, Florida). Bull Mar Sci 82:59-82

Kimmance SA, Wilson WH, Archer SD (2007) Modified dilution technique to estimate viral versus grazing mortality of phytoplankton: limitations associated with method sensitivity in natural waters. Aquat Microb Ecol 49: 207-222

Landry MR, Hassett RP (1982) Estimating the grazing impact of marine micro-zooplankton. Mar Biol 67:283-288

Lehrter JC, Pennock JR, McManus GB (1999) Microzooplankton grazing and nitrogen excretion across a surface estuarine-coastal interface. Estuaries 22:113-125

- McManus GB, Ederington-Cantrell MC (1992) Phytoplankton pigments and growth rates, and microzooplankton grazing in a large temperate estuary. Mar Ecol Prog Ser 87:77-85

McManus GB, Griffin PM, Pennock JR (2004) Bacterioplankton abundance and growth in a river-dominated estuary: relationships with temperature and resources. Aquat Microb Ecol 37:23-32

Murrell MC, Stanley RS, Lores EM, DiDonato GT, Flemer DA (2002a) Linkage between microzooplankton grazing and phytoplankton growth in a Gulf of Mexico estuary. Estuaries 25:19-29

Murrell MC, Stanley RS, Lores EM, DiDonato GT, Smith LM, Flemer DA (2002b) Evidence that phosphorus limits phytoplankton growth in a Gulf of Mexico estuary: Pensacola Bay, Florida, USA. Bull Mar Sci 70:155-167

> Ortmann AC, Metzger RC, Liefer JD, Novoveska L (2011) Grazing and viral lysis vary for different components of the microbial community across an estuarine gradient. Aquat Microb Ecol 65:143-157

> Payet JP, Suttle CA (2008) Physical and biological correlates

Editorial responsibility: Klaus Jürgens, Rostock, Germany of virus dynamics in the southern Beaufort Sea and Amundsen Gulf. J Mar Syst 74:933-945

Schroeder WW (1978) Riverine influence on estuaries: a case study. In: Wiley ML (ed) Estuarine interactions. Academic Press, New York, NY, p 347-364

Sherr EB, Caron DA, Sherr BF (1993) Staining of heterotrophic protists for visualization via epifluorescence microscopy. In: Kemp PF, Sherr BF, Sherr EB, Cole JJ (eds) Handbook of methods in aquatic microbial ecology. Lewis Publishers, Boca Raton, FL, p 213-228

Shifrin NS (1980) The measurement of dissolved organic carbon released by phytoplankton. Estuaries 3:230-233

Shoaf WT, Lium BW (1976) Improved extraction of chlorophyll $a$ and $b$ from algae using dimethyl sulfoxide. Limnol Oceanogr 21:926-928

Strom SL, Brainard MA, Holmes JL, Olsen MB (2001) Phytoplankton blooms are strongly impacted by microzooplankton grazing in coastal North Pacific waters. Mar Biol 138:355-368

Stumpf RP, Gelfenbaum G, Pennock JR (1993) Wind and tidal forcing of a buoyant plume, Mobile Bay, Alabama. Cont Shelf Res 13:1281-1301

Suttle CA, Chen F (1992) Mechanisms and rates of decay of marine viruses in seawater. Appl Environ Microbiol 58: 3721-3729

Suttle CA, Chan AM, Cottrell MT (1990) Infection of phytoplankton by viruses and reduction of primary productivity. Nature 347:467-469

Tijdens M, Van de Waal DB, Slovackova H, Hoogveld HL, Gons HJ (2008) Estimates of bacterial and phytoplankton mortality caused by viral lysis and microzooplankton grazing in a shallow eutrophic lake. Freshw Biol 53: 1126-1141

Tsai AY, Gong GC, Hung J (2012) Seasonal variations of viral- and nanoflagellate-mediated mortality of heterotrophic bacteria in the coastal ecosystem of subtropical western Pacific. Biogeosciences Discuss 9:17235-17261

> Tsai AY, Gong GC, Sanders RW, Juang JK (2013) Contribution of viral lysis and nanoflagellate grazing to bacterial mortality in the inner and outer regions of the Chanjiang River plume during summer. J Plankton Res 35: 1283-1293

> Weinbauer MG, Peduzzi P (1995) Significance of viruses versus heterotrophic nanoflagellates for controlling bacterial abundance in the northern Adriatic Sea. J Plankton Res 17:1851-1856

- Weinbauer MG, Bonilla-Findji O, Chan AM, Dolan JR and others (2011) Synechococcus growth in the ocean may depend on the lysis of heterotrophic bacteria. J Plankton Res 33:1465-1476

> Wen K, Ortmann AC, Suttle CA (2004) Accurate estimation of viral abundance by epifluorescence microscopy. Appl Environ Microbiol 70:3862-3867

Whitledge TE, Malloy SC, Patton CJ, Wirick CD (1981) Automated nutrient analyses in seawater. Brookhaven National Laboratory, Brookhaven, NY

Wilhelm SW, Suttle CA (1999) Viruses and nutrient cycles in the sea. BioScience 49:781-788

York JK, Costas BA, McManus GB (2010) Microzooplankton grazing in green water-results from two contrasting estuaries. Estuaries Coasts 34:373-385

Submitted: April 8, 2013; Accepted: January 28, 2014

Proofs received from author(s): March 17, 2014 